5 Research Square
Preprints are preliminary reports that have not undergone peer review.

They should not be considered conclusive, used to inform clinical practice, or referenced by the media as validated information.

\title{
Silencing of Estrogen receptor $\beta$ promotes the invasion and migration of osteosarcoma cells through activating Wnt signaling pathway
}

Yiping Zhang ( $\nabla$ yiping202020@163.com)

Basic Medical College of Jiujiang University https://orcid.org/0000-0002-8931-5716

Changchang Yin

Basic Medical College of Jiujiang University

Xufeng Zhou

Basic Medical College of Jiujiang University

Yahua Wu

Basic Medical College of Jiujiang University

Lili Wang

Basic Medical College of Jiujiang University

\section{Research article}

Keywords: Estrogen receptor $\beta$, Osteosarcoma, Wnt signaling pathway, Invasion, Migration

Posted Date: July 2nd, 2019

DOI: https://doi.org/10.21203/rs.2.10887/v1

License: (9) This work is licensed under a Creative Commons Attribution 4.0 International License.

Read Full License

Version of Record: A version of this preprint was published at OncoTargets and Therapy on August 1st, 2019. See the published version at https://doi.org/10.2147/OTT.S219222. 


\section{Abstract}

Background This study aimed to evaluate the specific roles of Estrogen receptor $\beta$ (ER $\beta$ ) on the invasion and migration of osteosarcoma (OS) cells, and explore the regulatory mechanisms relating with Wnt signaling pathway. Methods The expression of ER $\beta$ was detected on human OS tissues by quantitative real-time PCR and immunohistochemistry. U2-OS cells were transfected with siRNA-ERß (si-ER $\beta$ ) to downrgulate ER $\beta$, and treated with FH535 to inhibit Wnt signaling. The migration and invasion ability was detected by scratch and transwell assay, respectively. The expression of $\beta$-catenin, MMP-7 and MMP-9 was detected by Western blot. Subcutaneous tumor-bearing model was established by injection of U2-OS cells into mice, and the tumor volumes were measured. Orthotopic transplantation model was established by transplantation of tumor tissues into the liver of mice, and the metastatic tumors were counted. Results ER $\beta$ was downregulated in human OS tissues and U2-OS cells. The transfection of si-ER $\beta$ significantly increased the scratch healing rate, the number of invasion cells, and the expression of $\beta$ catenin, MMP-7 and MMP-9 in U2-OS cells. The injection of si-ERß-transfected U2-OS cells into mice significantly increased the subcutaneous tumor volume, the expression of $\beta$-catenin, MMP-7 and MMP-9, and the number of metastatic tumors in liver tissues. The promoting effects of si-ER $\beta$ on the invasion and migration of U2-OS cells were significantly reversed by FH535 in vitro and vivo. Conclusions Silencing of ER $\beta$ promotes the invasion and migration of OS cells via activating Wnt signaling pathway.

\section{Background}

Osteosarcoma (OS) is a common malignant bone tumor that usually develops in teenagers ${ }^{1}$. It is estimated that the incidence of OS is 4 million/year worldwide, with a peak at the age of 15-19 years ${ }^{2}$. The clinical outcomes of patients with metastatic OS are extremely poor ${ }^{3}$. The 5 -year survival of localized OS is about $65 \%-70 \%$, while the 5 -year survival of metastatic OS is only less than $20 \%{ }^{4}$. The discovery of novel therapeutic targets against metastatic OS are urgently needed.

Estrogen receptor $\beta$ (ERB), also known as nuclear receptor subfamily 3 group A (NR3A2) is an important transcription factor that involved in the occurrence and development of cancers ${ }^{5}$. ER $\beta$ has been considered as a potential therapeutic target in cancers, which can significantly inhibit the proliferation of diverse cancer cell lines, such as colon cancer SW480 cells ${ }^{6}$, breast cancer MCF-7 cells ${ }^{7}$, prostate cancer DU145 cells ${ }^{8}$, and OS U2-OS cells ${ }^{9}$. Note worthily, ER $\beta$ also exerts an obvious inhibitory role on the invasion and migration of cancer cells. It has been reported that ER 31 significantly inhibits the migration and invasion of breast cancer cells, as well as the tumor formation in mice ${ }^{10,11}$. ERß1 inhibits the invasion and migration of breast cancer cells in vitro, and the invasion, dissemination and micrometastasis of breast cancer cells in vivo ${ }^{12}$. In addition, a pervious study has proved that ER $\beta$ significantly promoted the migration and invasion of OS cells ${ }^{9}$. However, the regulatory mechanisms of ERß on OS are not fully revealed. 
Wnt signaling pathway is a $\beta$-catenin-dependent extracellular pathway that involved in a multitude of cellular processes, such as proliferation, apoptosis, differentiation, and migration ${ }^{13}$. The inhibition of Wnt signaling pathway has been proved to promote the migration and invasion of OS cells by various studies. For examples, the upregulation of naked cuticle homolog 2 (NKD2), a negative regulator of Wnt signaling pathway decreases the migration and invasion ability of OS cells in vitro, and inhibits the tumor metastasis in vivo ${ }^{14}$. The transfection of $\beta$-catenin siRNA decreases the invasion ability of OC cells through downregulating membrane type-1 matrix metalloproteinase (MT1-MMP) ${ }^{15}$. In addition, a previous study has proved that Erb-041, an ERß agonist inhibits skin photocarcinogenesis in mice though downregulating Wnt signaling pathway ${ }^{16}$. However, the specific regulatory relationship between ER $\beta$ and Wnt signaling pathway on OS is still unclear.

In this study, ER $\beta$ was silenced by siRNA-ER $\beta$ (si-ER $\beta$ ). The specific roles of si-ER $\beta$ on the migration and invasion of U2-OS cells were evaluated in both vitro and vivo. In addition, the regulatory mechanisms of ER $\beta$ relating with Wnt signaling pathway were investigated. Our findings may provide a novel therapeutic target, and a new insight into the underlying mechanisms for the treatment of metastatic OS.

\section{Methods}

\section{Clinical specimens}

A total of 24 patients ( 11 male and 13 female; $14-51$ years old) histologically diagnosed as OS (14 distal femur and 10 proximal tibia) were screened from our hospital between January 2016 and January 2018. Paraffin-embedded OS tissues, and adjacent normal tissues were collected form these patients prior to administering any treatment. This study was approved by the local Institutional Review Board, and informed consents were obtained from all subjects.

\section{Immunohistochemistry (IHC)}

Paraffin-embedded tissues were sliced at $5 \mu \mathrm{m}$, dewaxed in xylene, dehydrated with graded ethanol, incubated in $0.3 \% \mathrm{H}_{2} \mathrm{O}_{2}$ for $15 \mathrm{~min}$, and incubated in $10 \mathrm{mM}$ ethylene diamine tetraacetic acid (EDTA) for 15 min under microwave irradiation. The sections were blocked with $10 \%$ bovine serum albumi (BSA) for $30 \mathrm{~min}$, and incubated with primary antibody (anti-ER $\beta, 1: 100$, Cell Signaling, USA) for $3 \mathrm{~h}$ at $37^{\circ} \mathrm{C}$. Then the sections were washed with PBS for 5 times, and incubated with horseradish peroxidase (HRP)conjugated secondary antibody $\left(1: 1000\right.$, Cell Signaling) for $1 \mathrm{~h}$ at $37^{\circ} \mathrm{C}$. Followed by staining with diaminobenzidine (DAB), dehydration with graded ethanol and vitrification with dimethylbenzene, positive stained cells (yellow-brown or brown) were observed under microscope (Olympus, Japan), and counted in five randomly selected fields.

\section{Cell culture and treatments}

Human OS cell line U2-OS and human osteoblast cell line hFOB1.19 (preserved in our laboratory) were cultured in Dulbecco's Modified Eagle Medium (DMEM) containing 10\% fetal bovine serum (FBS) and 1\% 
penicillin-streptomycin. Cells were maintained in a humidified incubator containing at $37^{\circ} \mathrm{C}$ with $5 \% \mathrm{CO} 2$.

U2-OS cells in logarithmic growth phase were randomly divided into four groups: si-ER $\beta$, U2-OS cells transfected with si-ER (Santa Cruz Biotechnology, USA) for 48 h; NC-ERB, U2-OS cells transfected with siRNA-negative control-ER $\beta$ for $48 \mathrm{~h}$; si-ER $\beta$ + FH535, U2-OS cells transfected with siRNA-ER $\beta$ and treated with $20 \mu \mathrm{mol} / \mathrm{L}$ FH535 (an inhibitor of Wnt signaling) (Sigma, USA) for 48 h; Blank, U2-OS cells without transfection and treatment. Cell transfection was performed by using lipfectamine 2000 (Thermo Fisher Scientific, USA) according to the manufacturer's instruction.

\section{Quantitative real-time PCR (qRT-PCR)}

Total RNAs were extracted from specific tissues, and cells by using RNApreppure tissue kit (TIANGEN, China), and RNApreppure cell kit (TIANGEN), respectively. cDNA was synthesized by using PrimeScript RT reagent kit (Takara, China). The special primers were used as followed: ERß-F, 5'-

GCCGCCCCATGTGCTGAT-3'; ERß-R, 5'-GGACCCCGTGATGGAGGACTT-3'; $\beta$-catenin-F, 5'-

TGAGGACAAGCCACAAGATTAC-3'; $\beta$-catenin-R, 5'- TCCACCAGAGTGAAAAGAACG-3'. GAPDH was used as an internal control (GAPDH-F, 5'-GAGTCAACGGATTTGGTCGT-3'; GAPDH-R: 5'-

TTGATTTTGGAGGGATCTC-3'). The PCR program included $95^{\circ} \mathrm{C}$ for $10 \mathrm{~min}, 40$ cycles of $95^{\circ} \mathrm{C}$ for $10 \mathrm{~s}$, $60^{\circ} \mathrm{C}$ for $20 \mathrm{~s}$, and $72^{\circ} \mathrm{C}$ for $34 \mathrm{~s}$. The relative expression levels of target genes were calculated using the 2 $\Delta \Delta \mathrm{Ct}$ method ${ }^{17}$.

\section{Western blot}

Cells of different groups were lysed in RIPA Lysis buffer (Thermo Fisher Scientific). Total proteins were separated by $10 \%$ sodium dodecyl sulfate-polyacrylamide gel electrophoresis (SDS-PAGE), and transferred to polyvinylidenefluoride (PVDF) membrane. The membrane was blocked with $5 \%$ skim milk in Tris Buffered Saline Tween (TBST) for $1 \mathrm{~h}$, and incubated with primary antibody (anti-ER $\beta$, -MMP-7, MMP-9, and $-\beta$-catenin; 1: 100, Cell Signaling) overnight at $4^{\circ} \mathrm{C}$. After washed with TBST for three times, the membrane was incubated with HRP-conjugated secondary antibody (1:1000, Abcam, England) for $2 \mathrm{~h}$ at $25^{\circ} \mathrm{C}$. The protein bands were visualized and quantified using a Gel Imaging System (Thermo Fisher Scientific).

\section{Immunofluorescence}

Cells of different groups were fixed in $4 \%$ paraformaldehyde for $20 \mathrm{~min}$ at $4^{\circ} \mathrm{C}$, and permeated in $0.1 \%$ Triton X-100 (MP Biomedicals, USA) for 5 min. Then cells were blocked with 5\% BSA for 30 min, and incubated with primary antibody (anti- $\beta$-catenin, 1:100, Abcam) overnight at $4^{\circ} \mathrm{C}$. After washed with PBS for 5 times, cells were incubated with Alexa Fluor 488-conjugated secondary antibody (1:500, Abcam) for $1 \mathrm{~h}$ at $37^{\circ} \mathrm{C}$. Followed by staining with DAPI (4,6-diamino-2-phenylindole), positive stained cells (green fluorescence) were observed under fluorescence microscope (Olympus).

\section{Scratch assay}


Cells of different groups were seeded at a density of $0.5 \times 10^{6} /$ well in 6 -well plates, and cultured overnight (more than $90 \%$ confluence). A wound track at approximately $5 \mathrm{~mm}$ was scored in each dish with a pipette head, and the debris was removed by 3 times of washing with phosphate buffer saline (PBS). After $48 \mathrm{~h}$ of culturing, the scratch healing state was observed under microscope (Olympus).

\section{Transwell assay}

Transwell assay was performed by using transwell chambers (Corning, USA). Cells of different groups were seeded at a density of $0.1 \times 10^{5} / \mu \mathrm{L}$ in the upper chamber (pre-coated with Matrigel). A total of $600 \mu \mathrm{L}$ DMEM containing $100 \mathrm{ng} / \mathrm{mL}$ stromal cell-derived factor-1 (SDF-1) were placed in the lower chamber. After incubated at $37^{\circ} \mathrm{C}$ for $24 \mathrm{~h}$, cells on the upper chamber were removed with cotton swabs. Cells on the lower chamber were fixed in formaldehyde for $30 \mathrm{~min}$ and stained with $0.1 \%$ crystal violet for $20 \mathrm{~min}$. Positive stained cells were observed under microscope (Olympus).

\section{Establishment of subcutaneous tumor-bearing model and orthotopic transplantation model in mice}

Four-week-old specific pathogen free (SPF) mice (male, 20-25g) were purchased from the Medical College of Shanghai Jiaotong University (Shanghai, China). Mice were feeding at $25^{\circ} \mathrm{C}$ and $50 \%$ humidity with free access to water and food. A total of $100 \mu \mathrm{l}$ U2-OS cells in different groups (si-ER $3, N C$-ER 3 , si-ER + FH535, and Blank) were subcutaneously injected into the posterior limb of each mouse at a density of $0.1 \times 10^{8} \mathrm{cell} s / \mathrm{ml}$ (subcutaneous tumor-bearing model). Mice were killed by cervical dislocation, and the tumor volumes were measured by vernier caliper every 5 days. After the injection for 20 days, small pieces of tumor tissues were transplanted into the liver of healthy mice (orthotopic transplantation model). Five weeks later, the metastatic tumors in liver tissues were counted, and observed by Hematoxylin-Eosin (HE) staining. All animal experiments were approved by the local Institutional Review Board.

\section{HE staining}

The liver tissues of mice were fixed in $10 \%$ formaldehyde, and embedded in paraffin. The tissue sections at $5 \mu \mathrm{m}$ were dewaxed in xylene, rehydrated in graded ethanol, and stained with Hematoxylin for 5 min and Eosin (Beyotime) for 2 min. After dehydrated with graded ethanol and vitrificated with dimethylbenzene, the tissues were observed under microscope (Olympus).

\section{Statistical analyses}

All experiments were performed in triplicate, and all data were expressed as mean \pm Standard Deviation (SD). Statistical analysis was performed by SPSS version 17.0 (SPSS Inc., Chicago, IL). Comparison between different groups was determined by Student's t test (two groups) and one-way ANOVA (more than two groups). A p-value less than 0.05 was considered to be significantly different.

\section{Results}




\section{ER $\beta$ was downregulated in human OS tissues}

The expression of ER $\beta$ was detected in OS tissues of 24 OS patients. qRT-PCR showed that the expression of ER $\beta$ was significantly lower in OS tissues than in adjacent normal tissues $(P<0.001)$ (Fig $1 \mathrm{~A})$. In addition, IHC showed that the positive cell rate was significantly lower in OS tissues than in adjacent normal tissues $(27.1 \pm 1.49 \%$ vs. $73.0 \pm 1.40 \%, \mathrm{P}<0.001)$ (Fig 1B)

\section{ER $\beta$ was downregulated in U2-OS cells}

The expression of ER $\beta$ was detected in U2-OS and hFOB1.1 cells. qRT-PCR and Western blot showed that the expression of ER $\beta$ was significantly lower in U2-OS cells than in hFOB1.1 cells at both mRNA and protein level $(P<0.001)$ (Fig $2 A$ and $B$ ). Then si-ER $\beta$ was used to silence ER $\beta$ in U2-OS cells. As shown in Fig $2 C$ and $D$, the expression of ER $\beta$ in U2-OS cells was significantly inhibited by si-ER $\beta$ at both mRNA and protein level $(P<0.01)$. No significantly different on the expression of ER $\beta$ was observed between blank and NC-ERß group (Fig 2C and D).

\section{si-ER $\beta$ transfection activated Wnt signaling pathway}

In order to evaluate the regulatory relationship between ER $\beta$ and Wnt signaling pathway, the expression of $\beta$-catenin was detected. Western blot showed that the expression of $\beta$-catenin was significantly higher in U2-OS cells than in hFOB1.1 cells at protein level $(P<0.01)$ (Fig 3A). U2-OS cells in si-ER $\beta$ group exhibited significantly higher expression of $\beta$-catenin than those in NC- ER $\beta$ and blank group $(P<0.001)$. However, the expression of $\beta$-catenin in si-ERß-transfected U2-OS cells was significantly inhibited by the intervention of FH535 ( $\mathrm{P}<0.01$ ) (Fig 3B). In addition, immunofluorescence showed that si-ER $\beta$ transfection significantly increased the fluorescence intensity of $\beta$-catenin in U2-OS cells, and promoted the nuclear aggregation of $\beta$-catenin. The intervention of FH535 significantly decreased the fluorescence intensity of $\beta$-catenin in si-ER $\beta$-transfected U2-OS cells, and inhibited the nuclear aggregation of $\beta$-catenin (Fig 3C).

\section{si-ERß transfection promoted the migration of U2-OS cells}

The effect of si-ERß on the migration of U2-OS cells was evaluated. Scratch assay showed that U2-OS cells in si-ER $\beta$ group exhibited significantly higher scratch healing rate than those in NC-ER $\beta$ and blank group $(72.47 \pm 3.19 \%$ vs. $33.56 \pm 3.42 \%$ and $31.47 \pm 3.19, \mathrm{P}<0.001)$. The intervention of FH535 significantly decreased the scratch healing rate in si-ERß-transfected U2-OS cells (32.47 \pm 2.19 vs. $72.47 \pm$ $3.19 \%, P<0.001)$ (Fig 4A and B).

\section{si-ER $\beta$ transfection promoted the invasion of U2-OS cells}

The effect of si-ER $\beta$ on the invasion of U2-OS cells was evaluated. Transwell assay showed that the number of invasion cells was significantly higher in si-ER $\beta$ group than in NC-ER $\beta$ and blank group (76.11 $\pm 2.97 \%$ vs. $39.41 \pm 1.89 \%$ and $35.51 \pm 3.84, \mathrm{P}<0.001)$. The intervention of FH535 significantly decreased the number of invasion cells in si-ERß-transfected U2-OS cells $(36.11 \pm 2.97$ vs. $76.11 \pm 2.97 \%$, 
$P<0.001$ ) (Fig 5A and B). In addition, Western blot showed that the expression of MMP-7 and MMP-9 in U2-OS cells was significantly higher in si-ER $\beta$ group than in NC-ER $\beta$ and blank group $(P<0.001)$. The intervention of FH535 significantly decreased the expression of MMP-7 and MMP-9 in si-ERß-transfected U2-OS cells $(P<0.001)$ (Fig 5 C and $D)$.

\section{si-ER $\beta$ transfection promoted the growth and metastasis of OS tumors in mice}

In order to further evaluate the pro-migratory and -invasive effects of si-ERß in vivo, subcutaneous tumorbearing model was established in mice. As shown in Fig $6 A$ and $B$, the tumor volumes in mice of different groups were all significantly increased in a time-dependent manner. The tumor volumes were significantly higher in si-ER $\beta$ group than in NC-ER $\beta$ and blank group, beginning from the 10th day $(P<0.001)$. The intervention of FH535 significantly decreased the tumor volumes in mice injected with si-ERß-transfected U2-OS cells $(P<0.001)$ (Fig $6 \mathrm{~A}$ and $\mathrm{B})$. In addition, Western blot showed that the expression of $\beta$-catenin, MMP-7 and MMP-9 in tumor tissues was significantly higher in si-ER $\beta$ group than in NC-ER $\beta$ and blank group $(P<0.001)$. The intervention of FH535 significantly decreased the expression of $\beta$-catenin, MMP-7 and MMP-9 in tumor tissues of mice injected with si-ERß-transfected U2-OS cells $(P<0.001)$ (Fig $6 \mathrm{C}$ and D). Furthermore, the metastatic ability of si-ERß-transfected U2-OS cells was evaluated in a mouse model of orthotopic transplantation. As shown in Fig $6 \mathrm{E}$ and $\mathrm{F}$, more metastatic tumors were observed in the liver tissues of mice in si-ER $\beta$ group than in NC-ER $\beta$ and blank group $(P<0.001)$. The intervention of FH535 significantly decreased the number of metastatic tumors in the liver tissue of mice injected with siERß-transfected U2-OS cells $(P<0.001)$ (Fig 6E and F).

\section{Discussion}

ER $\beta$ is an estrogen-regulated transcription factor that plays a critical role in the progression of cancers ${ }^{18}$. A large number of pervious studies have proved that ER $\beta$ is downregulated in diverse cancers, such as breast cancer ${ }^{19}$, ovarian cancer ${ }^{20}$, prostatic cancer ${ }^{21}$, and colon cancer ${ }^{22}$. In this study, the expression of ER $\beta$ was detected in both human OS tissues and U2-OS cells. We found that the expression of ER $\beta$ was significantly lower in OS tissues than in adjacent normal tissues, and significantly lower in U2-OS cells than in hFOB1.1 cells. Our findings are just consistent with pervious studies, and illustrate that ER $\beta$ is downregulated in OS.

The inhibition of cell invasion and migration is an important anti-tumor manifestation of ER $\beta$ on cancers 23,24 . In this study, the invasion and migration abilities of si-ERß-transfected U2-OS cells were evaluated. We found that the transfection of si-ER $\beta$ into U2-OS cells significantly increased the scratch healing rate and number of invasion cells. These findings are just consistent with a pervious study that the knockdown of ERß significantly increases the migration and invasion abilities of U2-OS cells ${ }^{9}$. In order to further identify the pro-migratory and -invasive effects of si-ER $\beta$ in vivo, subcutaneous tumor-bearing model and orthotopic transplantation model were established in mice. We found that the injection of siERB-transfected U2-OS cells significantly increased the subcutaneous tumor volume, and the number of metastatic tumors in liver tissues of mice. These phenomena indicate that si-ER $\beta$ promotes the growth 
and metastasis of OS tumors in vivo, which are consistent with pervious studies on animal models of breast cancer. It has been reported that exogenous ERß expression significantly inhibits the growth of MCF-7 tumor xenografts in mice, and tumors are only observed in 2/6 mice injected with MCF-7-ER ${ }^{25}$. MDA-MB-231 cells are disseminated away from the injection site of zebrafish at 5th day post-injection, while ERß1-expressing MD-MB-231 cells remain at the primary site ${ }^{12}$. In addition, we also found that siERß significantly increased the expression of MMP-7 and MMP-9 in U2-OS cells and OS tumors of mice. Since MMP-7 and MMP-9 are positively associated with tumor metastasis ${ }^{26,27}$, the upregulated MMP-7 and MMP-9 contribute to the promoting effects of si-ERß on the invasion and migration of U2-OS cells in vitro and on the growth and metastasis of OS tumors in vivo.

The anti-tumor mechanisms of ER $\beta$ are complex, which related with diverse regulatory factors, such as Ecadherin ${ }^{10}$, epidermal growth factor receptor (EGFR) ${ }^{28}$, transforming growth factor $\beta$ (TGF $\left.\beta\right)^{29}$, p53-

upregulated modulator of apoptosis (PUMA) ${ }^{30}$, nuclear factor-kB/B-cell lymphoma-2 (NF-kB/BCL-2) and phosphatidylinositol-3 kinase/Akt (PI3K/Akt) ${ }^{9}$. In this study, the regulatory relationship between ER $\beta$ and Wnt signaling pathway was evaluated on U2-OS cells. We found that the si-ER $\beta$ significantly upregualted $\beta$-catenin in U2-OS cells, which indicates that the downregulation of ER $\beta$ activates the Wnt signaling pathway in U2-OS cells. The activation of Wnt signaling pathway contributes to promoting the invasion and migration of OS cells. Pervious studies have proved that the upregulation of NKD2 (a negative regulator of Wnt signaling) and the transfection of $\beta$-catenin siRNA can both decrease the migration and invasion abilities of OS cells through inhibiting Wnt signaling pathway ${ }^{14,15}$. Therefore, we suspect that si-ER $\beta$ may promote the invasion and migration of U2-OS cells through activating Wnt signaling pathway. This hypothesis is further confirmed by the intervention of FH535. We found that the intervention of FH535 significantly decreased the scratch healing rate, the number of invasion cells, and the expression of MMP-7 and MMP-9 in U2-OS cells transfected with si-ERß. In addition, $\beta$-catenin was also upregulated in OS tumors of mice injected with si-ER $\beta$-transfected U2-OS cells. The intervention of FH535 in mice injected with si-ERß-transfected U2-OS cells significantly decreased the subcutaneous tumor volume, the expression of $\beta$-catenin, MMP-7 and MMP-9, as well as the number of metastatic tumors in liver tissues. These results further illustrate that the promoting effects of si-ER $\beta$ on the growth and metastasis of OS tumors in mice may attribute to the activation of Wnt signaling pathway.

\section{Conclusions}

In conclusion, si-ER $\beta$ significantly promoted the invasion and migration of U2-OS cells in vitro, and the growth and metastasis of OS tumors in vivo. The promoting effects of si-ER $\beta$ on OS metastasis was closely related with the activation of Wnt signaling pathway. ER $\beta$ might be a potential therapeutic target for metastatic OS. However, this study is limited in si-ER $\beta$. Further researches on the specific roles and regulatory mechanisms of ERß overexpression on OS metastasis are still needed.

\section{Abbreviations}


osteosarcoma (OS)

SiRNA-ERß (si-ERß)

\section{Declarations}

Ethics approval and consent to participate: The ethics committee of Basic Medical College of Jiujiang University approved the study The study was written informed consent from the parents when participants are children (under 16 years old).

The study was performed in accordance with the the National Research Council (US) Committee Guide for the Care and Use of Laboratory Animals.

Consent for publication: Not applicable.

Availability of data and material: All data generated or analyzed during this study are included in this published article [and its supplementary information files].

Competing interests: The authors declare that they have no competing interests.

Funding: National Nature Science Foundation of China (No. 81360364) \Antitumor role and mechanisms of liquiritigenin-mediated ER $\beta$ isoform in the hypoxia microenviroment of hepatocellular carcinoma.

Authors' contributions: YPZ, TY and CCY designed and analyzed the experiment, and was a major contributor in writing the manuscript. XFZ, YHW and LLW performed the experiment. All authors read and approved the final manuscript.

Acknowledgements: Not applicable.

\section{References}

1. Jackson TM, Bittman M, Granowetter L. Pediatric Malignant Bone Tumors: A Review and Update on Current Challenges, and Emerging Drug Targets. Curr Probl Pediatr Adolesc Health Care. 2016;46:213-28.

2. Mirabello L, Troisi R, Sa. Osteosarcoma incidence and survival rates from 1973 to 2004: data from the Surveillance, Epidemiology, and End Results Program. Cancer. 2010;115:1531-43.

3. Mialou V, Philip T, Kalifa C, Perol D, Gentet JC, Marecberard P, et al. Metastatic osteosarcoma at diagnosis: prognostic factors and long-term outcome-the French pediatric experience. Cancer. 2010;104:1100-9.

4. Siegel HJ, Pressey JG. Current concepts on the surgical and medical management of osteosarcoma. Expert Rev Anticancer Ther. 2014;8:1257. 
5. Guillette TC, Jackson TW, Belcher SM. Duality of estrogen receptor $\beta$ action in cancer progression. Curr Opin Pharmacol. 2018;41:66-73.

6. Johan H, Karin E, Karolina L, Chunyan Z, Cecilia W, Anders SM, et al. Tumor repressive functions of estrogen receptor beta in SW480 colon cancer cells. Cancer Res. 2009;69:6100-6.

7. Sreenivasan P, Hema P, Vaishali K, Cunha GR, Firestone GL, Leitman DC. Estrogen receptor beta inhibits human breast cancer cell proliferation and tumor formation by causing a $\mathrm{G} 2$ cell cycle arrest. Cancer Res. 2004;64:423.

8. Shan $Y$, Wang $X$, Chan FL. Overexpression of estrogen receptor-related receptor $\beta$ (ERR $\beta$ ) suppresses the cell proliferation and tumor growth of androgen-dependent and -independent prostate cancer cells via induction of p21Cip1/Waf1. Cancer Res. 2006;66.

9. Yang $M$, Bing $L$, Jin $L$, Tao $H$, Yang Z. Estrogen receptor $\beta$ exhibited anti-tumor effects on osteosarcoma cells by regulating integrin, IAP, NF-kB/BCL-2 and PI3K/Akt signal pathway. J Bone Oncol. 2017;9:S2212137417300933.

10. Zhou Y, Ming J, Xu Y, Zhang Y, Jiang J. ERß1 inhibits the migration and invasion of breast cancer cells through upregulation of E-cadherin in a Id1-dependent manner. Biochem Biophys Res Commun. 2015;457:141-7.

11. Li H, Tu Z, An L, Qian Z, Achilefu S, Gu Y. Inhibitory effects of ERß on proliferation, invasion, and tumor formation of MCF-7 breast cancer cells--prognostication for the use of ERß-selective therapy. Pharm Biol. 2012;50:839-49.

12. Thomas C, Rajapaksa G, Nikolos F, Hao R, Katchy A, Mccollum CW, et al. ERß1 represses basal-like breast cancer epithelial to mesenchymal transition by destabilizing EGFR. Breast Cancer Res. 2012;14:R148.

13. Nusse R, Clevers H. Wnt/ $\beta$-Catenin Signaling, Disease, and Emerging Therapeutic Modalities. Cell. 2017;169:985.

14. Zhao S, ., Kurenbekova L, ., Gao Y, ., Roos A, ., Creighton CJ, Rao P, ., et al. NKD2, a negative regulator of Wnt signaling, suppresses tumor growth and metastasis in osteosarcoma. Oncogene. 2015;34:5069.

15. Fan Z, Anmin C, Jianfeng C, Tian Y, Fengjing G. SiRNA-mediated silencing of beta-catenin suppresses invasion and chemosensitivity to doxorubicin in MG-63 osteosarcoma cells. Asian Pac J Cancer Prev. 2011;12:239-45.

16. Chaudhary SC, Tripti S, Talwelkar SS, Srivastava RK, Aadithya A, Zhiping W, et al. Erb-041, an estrogen receptor- $\beta$ agonist, inhibits skin photocarcinogenesis in SKH-1 hairless mice by downregulating the WNT signaling pathway. Cancer Prevention Research. 2014;7:186.

17. Livak KJ ST. Analysis of Relative Gene Expression Data Using Real-Time Quantitative PCR and the 2(-Delta Delta C(T))Method. METHODS. 2001;Dec;25(4):402-8.

18. Warner M, Huang B, Gustafsson JA. Estrogen Receptor $\beta$ as a Pharmaceutical Target. Trends Pharmacol Sci. 2017;38:92. 
19. Alnakhle H, Burns PA, Cummings M, Hanby AM, Hughes TA, Satheesha S, et al. Estrogen Receptor $\beta 1$ Expression Is Regulated by miR-92 in Breast Cancer. Cancer Res. 2010;70:4778-84.

20. Lazennec G. Estrogen receptor beta, a possible tumor suppressor involved in ovarian carcinogenesis. Cancer Lett. 2006;231:151-7.

21. Daniels G, Gellert LL, Melamed J, Hatcher D, Li Y, Wei J, et al. Decreased expression of stromal estrogen receptor $\alpha$ and $\beta$ in prostate cancer. Am J Transl Res. 2014;6:140-6.

22. Campbellthompson M, Lynch IJ, Bhardwaj B. Expression of Estrogen Receptor (ER) Subtypes and ERß Isoforms in Colon Cancer. Cancer Res. 2001;61:632-40.

23. Thomas C, Rajapaksa G, Nikolos F, Gustafsson JA. Abstract 1384: Estrogen receptor beta inhibits migration and invasion of breast cancer cells by regulating E-cadherin levels. Cancer Res. 2011;71:1384-.

24. Tu Z, Ma Y, Tian J, Li H, Akers W, Achilefu S, et al. Estrogen receptor $\beta$ potentiates the antiproliferative effect of raloxifene and affects the cell migration and invasion in HCT-116 colon cancer cells. $J$ Cancer Res Clin Oncol. 2012;138:1091-103.

25. Hui L, Zhenzhen T, Lianxiao A, Zhiyu Q, Samuel A, Yueqing G. Inhibitory effects of ER $\beta$ on proliferation, invasion, and tumor formation of MCF-7 breast cancer cells-prognostication for the use of ERß-selective therapy. Pharm Biol. 2012;50:839-49.

26. Kim JH, Pyun JA, Lee KJ, Cho SW, Kwack KB. Study on association between single nucleotide polymorphisms of MMP7, MMP8, MMP9 genes and development of gastric cancer and lymph node metastasis. Korean J Gastroenterol. 2011;58:245.

27. Hsu TI, Lin SC, Lu PS, Chang WC, Hung CY, Yeh YM, et al. MMP7-mediated cleavage of nucleolin at Asp255 induces MMP9 expression to promote tumor malignancy. Oncogene. 2015;34:826.

28. Pinton G, Thomas W, Bellini P, Manente AG, Favoni RE, Harvey BJ, et al. Estrogen Receptor $\beta$ Exerts Tumor Repressive Functions in Human Malignant Pleural Mesothelioma via EGFR Inactivation and Affects Response to Gefitinib. 2010;5:e14110.

29. Zhao C, Dahlmanwright K, Gustafsson JA. Estrogen receptor $\beta$ : an overview and update. Nucl Recept Signal. 2008;4:e003.

30. Dey P, Ström A, Gustafsson JÅ. Estrogen receptor $\beta$ upregulates FOXO3a and causes induction of apoptosis through PUMA in prostate cancer. Oncogene. 2013;33:4213-25.

\section{Figures}


A

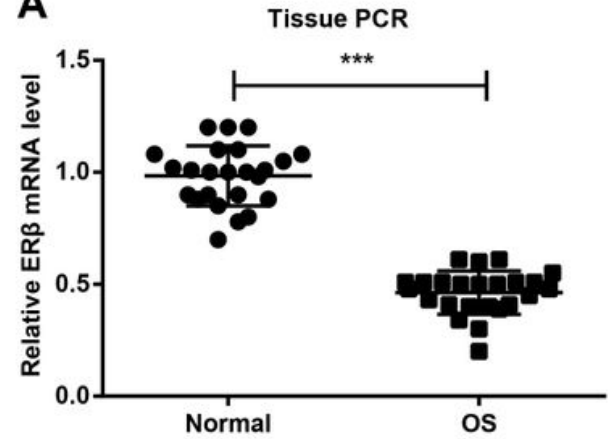

B

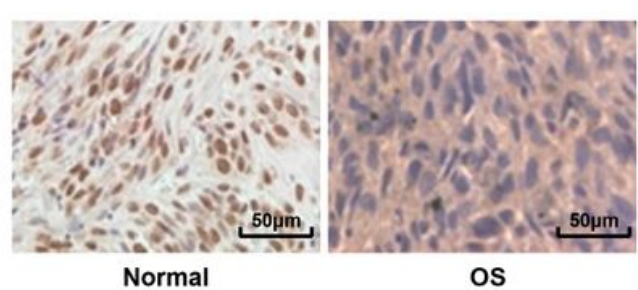

os

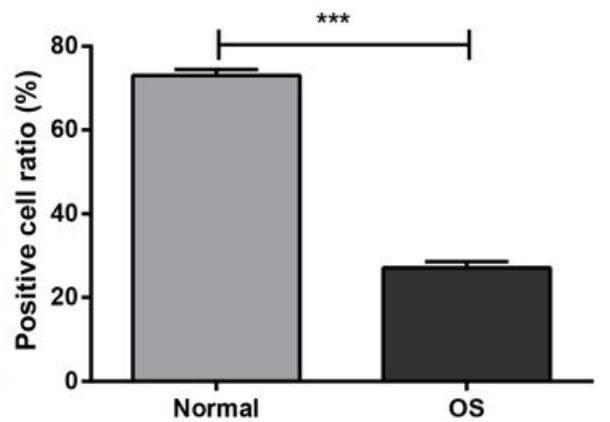

Figure 1

The expression of Estrogen receptor $\beta(E R \beta)$ in osteosarcoma (OS) and adjacent normal tissues of 24 OS patients detected by quantitative real-time PCR (qRT-PCR) and immunohistochemistry (IHC). A) relative expression of ER $\beta$ at mRNA level (qRT-PCR); B) positive stained cells. ***, $\mathrm{P}<0.001$.

A

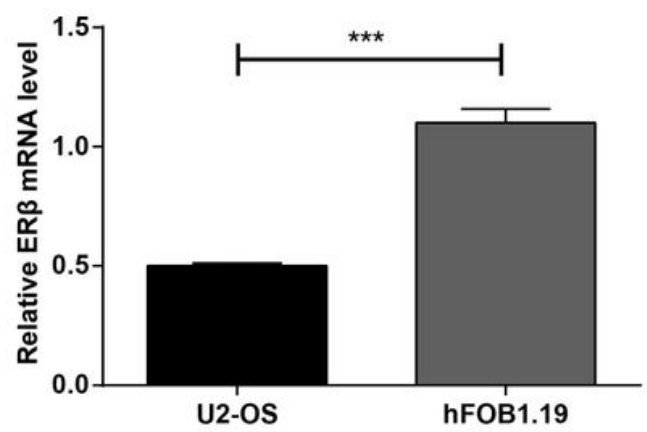

C

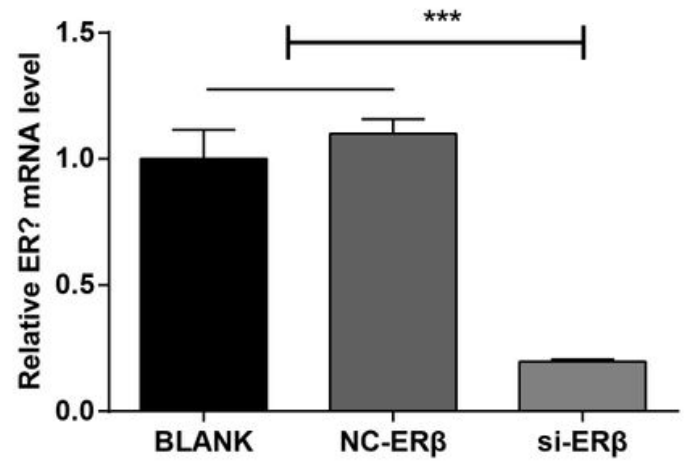

B
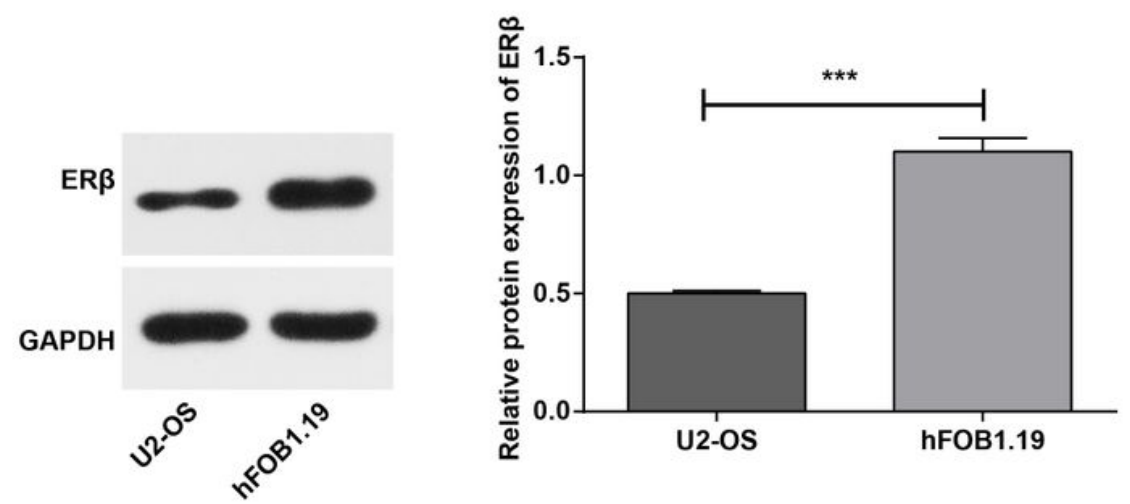

D

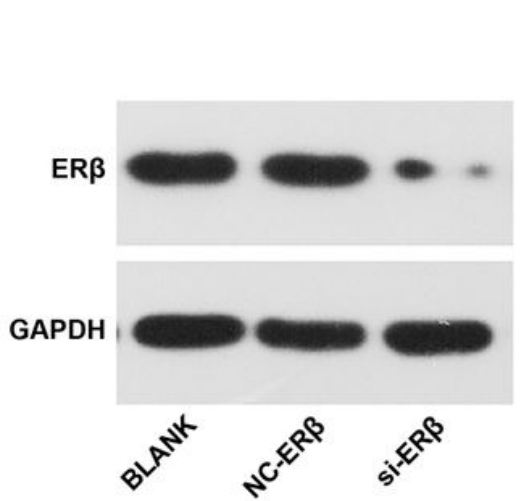

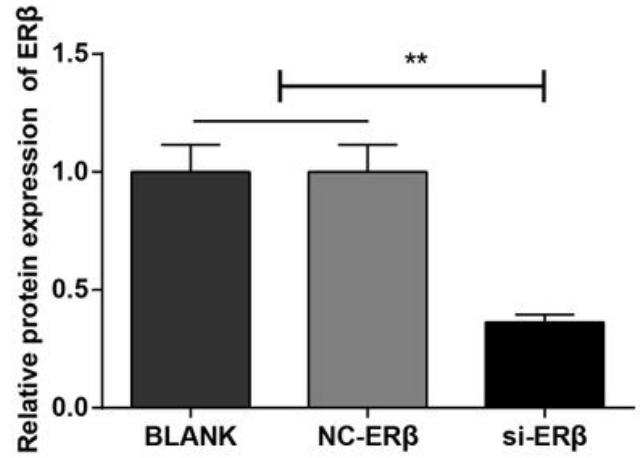

Figure 2

The expression of Estrogen receptor $\beta$ (ERB) in U2-OS and hFOB1.1 cells detected by quantitative realtime PCR (qRT-PCR) and Western blot. A and C) relative expression of ER $\beta$ at mRNA level (qRT-PCR); $B$ and $D$ ) relative expression of ER $\beta$ at protein level (Western blot). si-ER 3 , U2-OS cells transfected with siRNA-ER $\beta$ for $48 \mathrm{~h}$; NC-ER $\beta$, U2-OS cells transfected with siRNA-negative control-ER $\beta$ for $48 \mathrm{~h}$; Blank, U2OS cells without transfection. **, $\mathrm{P}<0.01 ; * \star \star, \mathrm{P}<0.001$. 

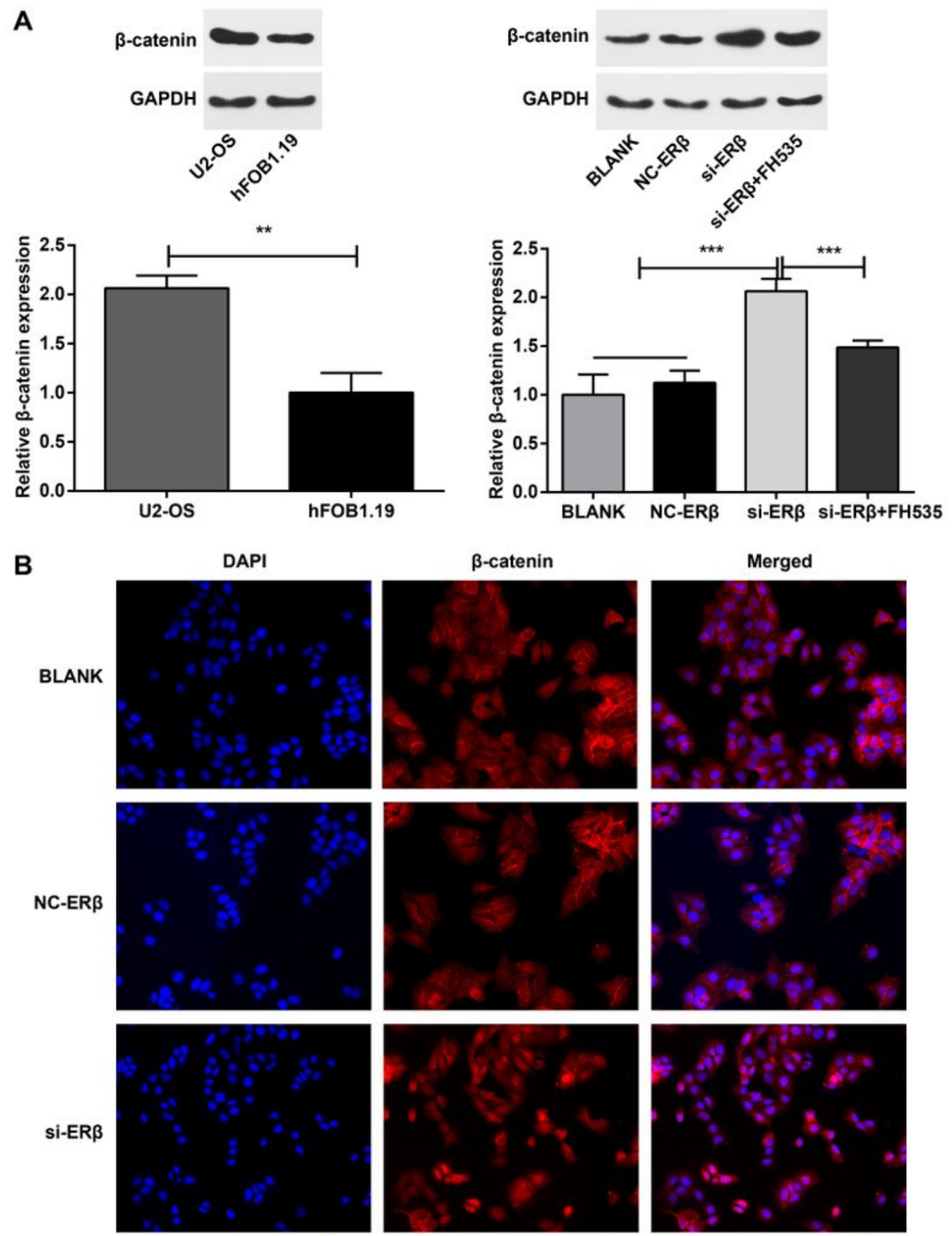

si-ER $\beta+F H 535$
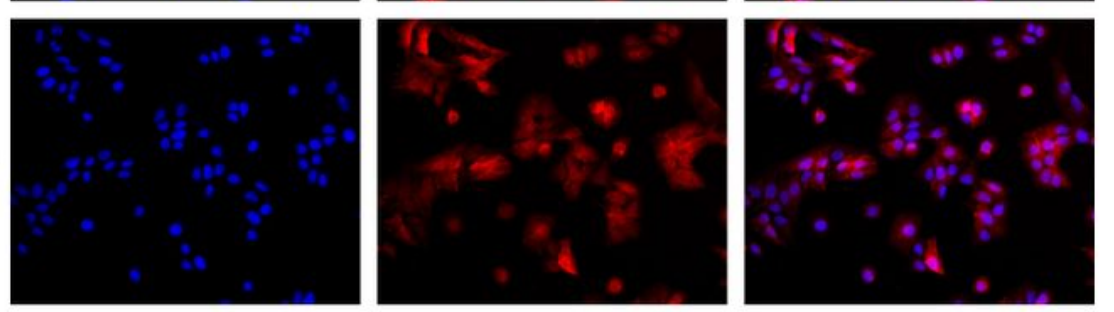

\section{Figure 3}

The expression of $\beta$-catenin in U2-OS and hFOB1.1 cells detected by Western blot and Immunofluorescence. $A$ and $B$ ) relative expression of $\beta$-catenin at protein level (Western blot); $C$ ) positive stained cells. si-ER $\beta$, U2-OS cells transfected with siRNA-ER $\beta$ for 48 h; NC-ER $\beta$, U2-OS cells transfected with siRNA-negative control-ER $\beta$ for $48 \mathrm{~h}$; si-ER $\beta$ + FH535, U2-OS cells transfected with siRNA-ER $\beta$ and 
treated with $20 \mu \mathrm{mol} / \mathrm{L}$ FH535 for 48 h; Blank, U2-OS cells without transfection and treatment. **, $\mathrm{P}<$ $0.01 ; * \star *, P<0.001$.

A
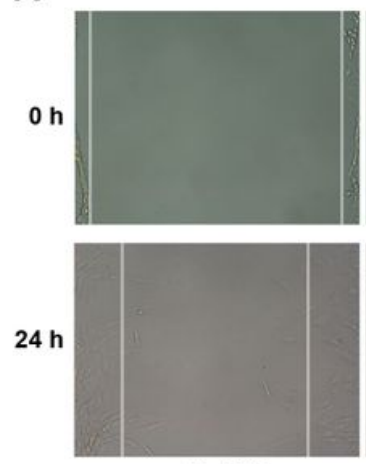

BLANK

C

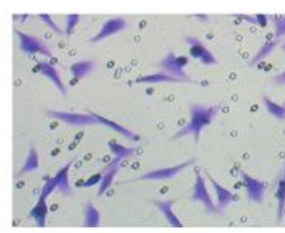

BLANK
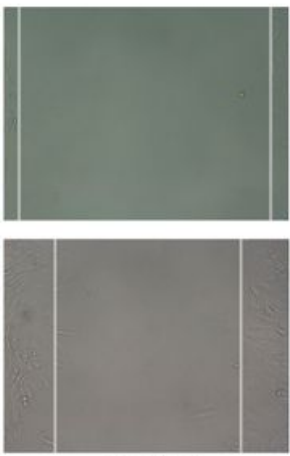

NC-ER $\beta$
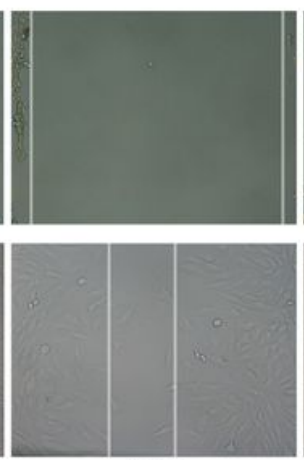

si-ER $\beta$
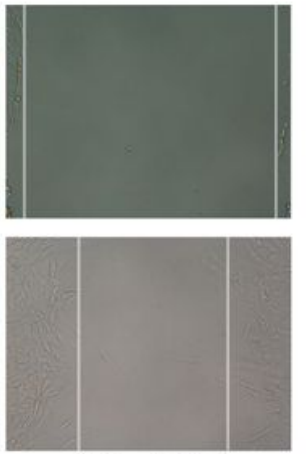

si-ER $\beta+F H 535$

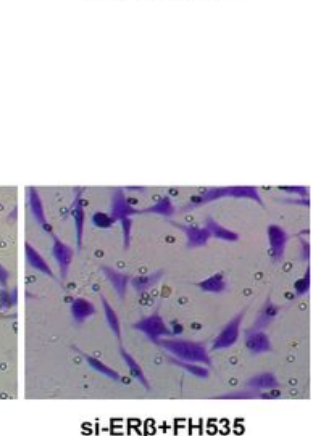

B

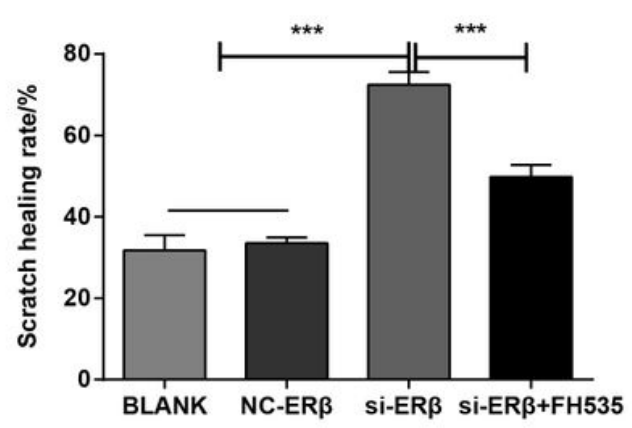

D

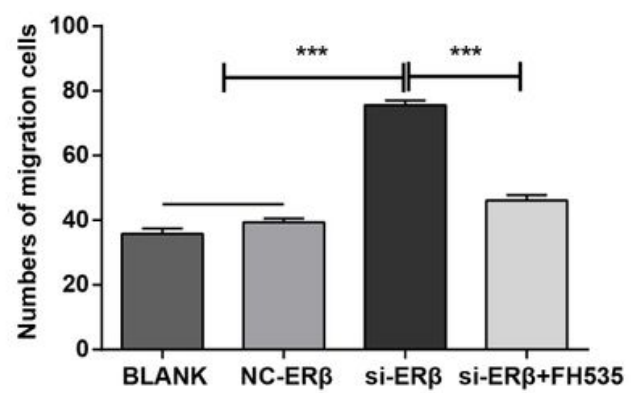

Figure 4

The migration of U2-OS cells detected by Scratch assay. A) scratch healing under microscope; B) scratch healing rate. si-ER $\beta$, U2-OS cells transfected with siRNA-ER $\beta$ for 48 h; NC-ER $\beta$, U2-OS cells transfected with siRNA-negative control-ER $\beta$ for 48 h; si-ER + FH535, U2-OS cells transfected with siRNA-ER $\beta$ and

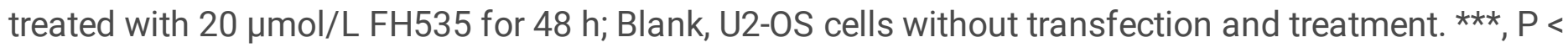
0.001 . 
A

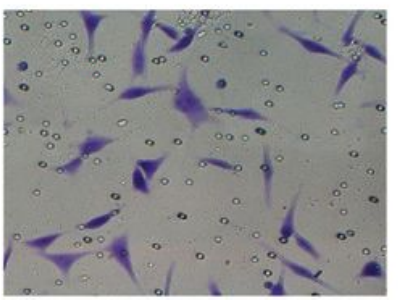

BLANK

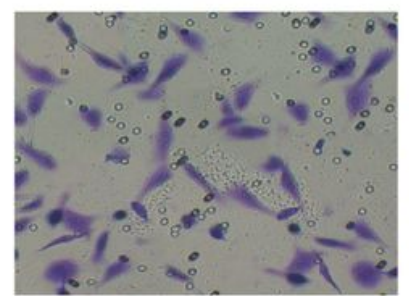

si-ER $\beta$

C

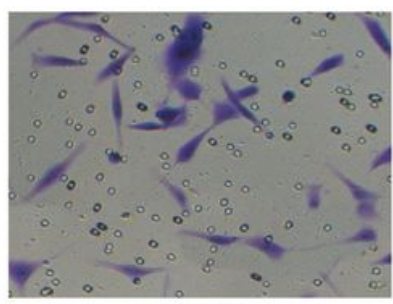

NC-ER $\beta$

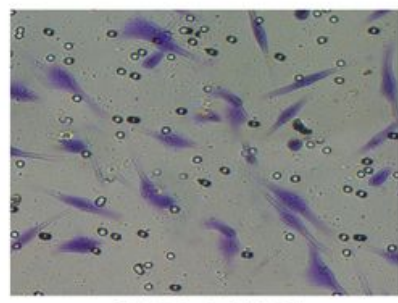

si-ERß+FH535
B

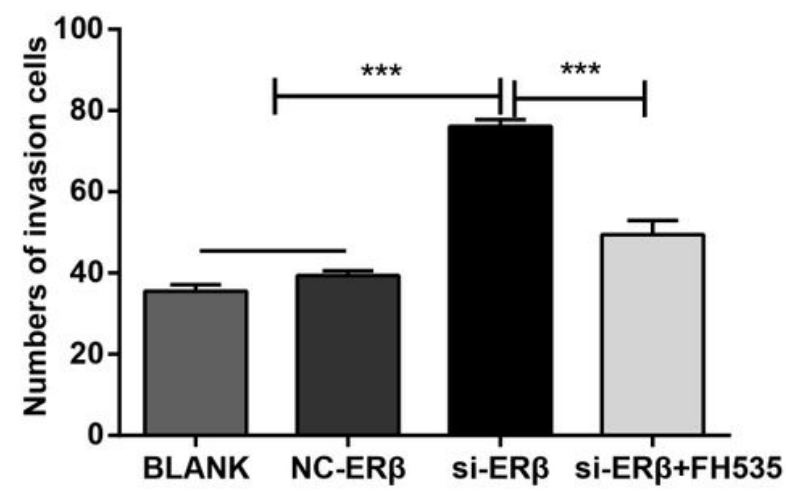

D

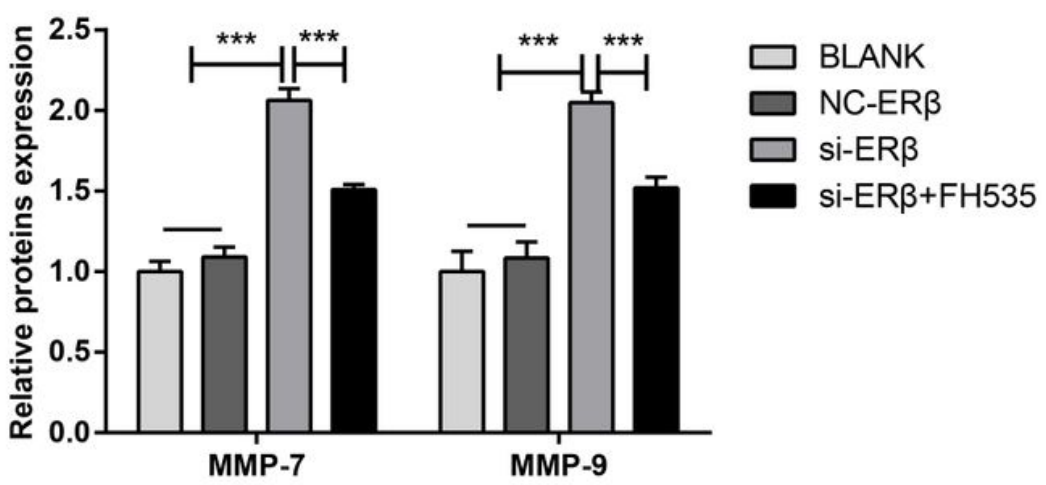

\section{Figure 5}

The invasion of U2-OS cells detected by Transwell assay and Western blot. A) invasion cells under microscope; B) number of invasion cells; C) protein brands of Western blot; D) relative expression of MMP-7 and MMP-9 at protein level (Western blot). si-ER $\beta$, U2-OS cells transfected with siRNA-ER $\beta$ for 48 h; NC-ER $\beta$, U2-OS cells transfected with siRNA-negative control-ER $\beta$ for 48 h; si-ERß + FH535, U2-OS cells transfected with siRNA-ER $\beta$ and treated with $20 \mu \mathrm{mol} / \mathrm{L}$ FH535 for 48 h; Blank, U2-OS cells without transfection and treatment. ${ }^{\star \star \star}, \mathrm{P}<0.001$. 
A

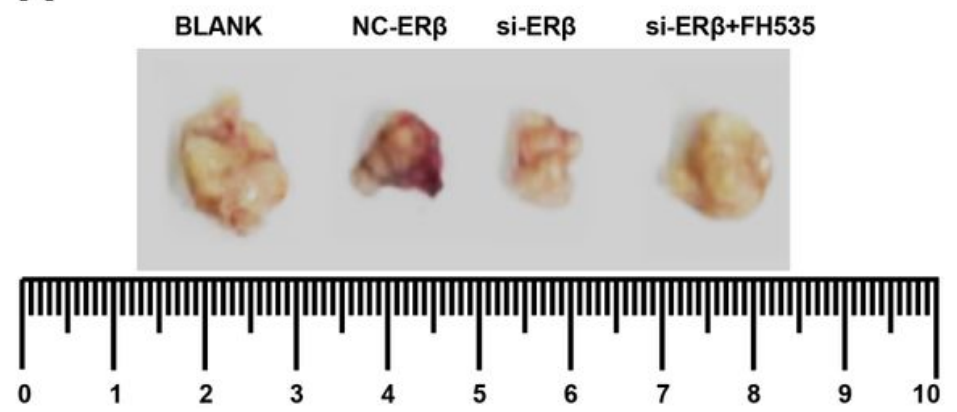

C
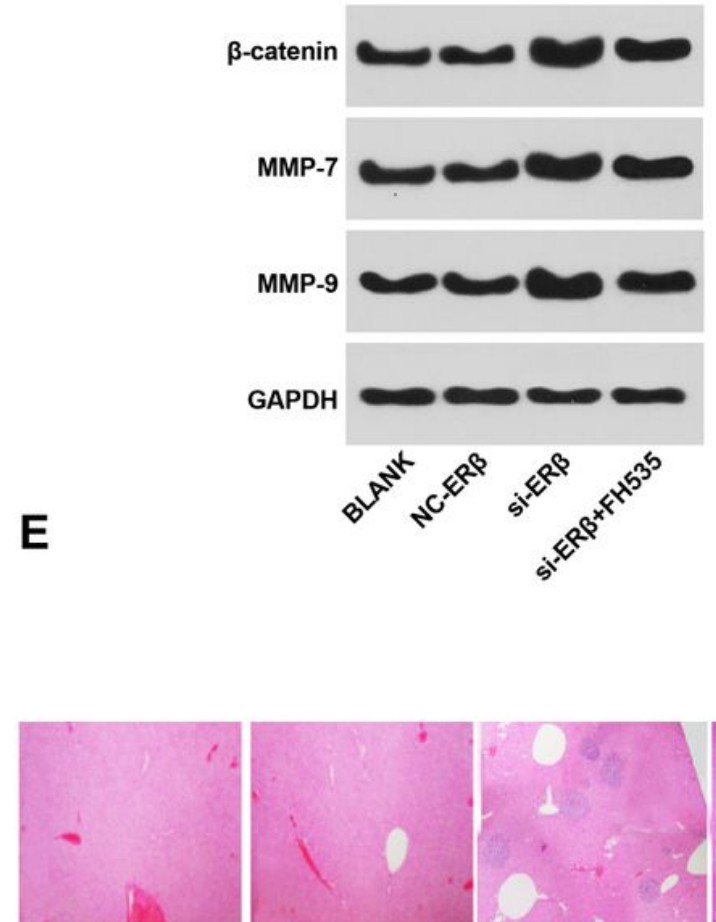

BLANK

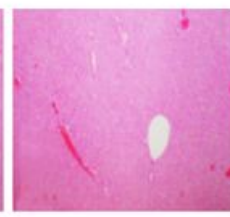

NC-ER $\beta$

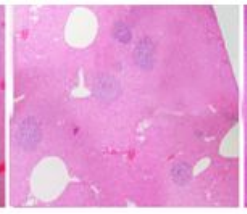

si-ER $\beta$

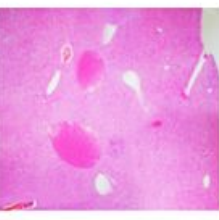

si-ER $\beta+F H 535$
B
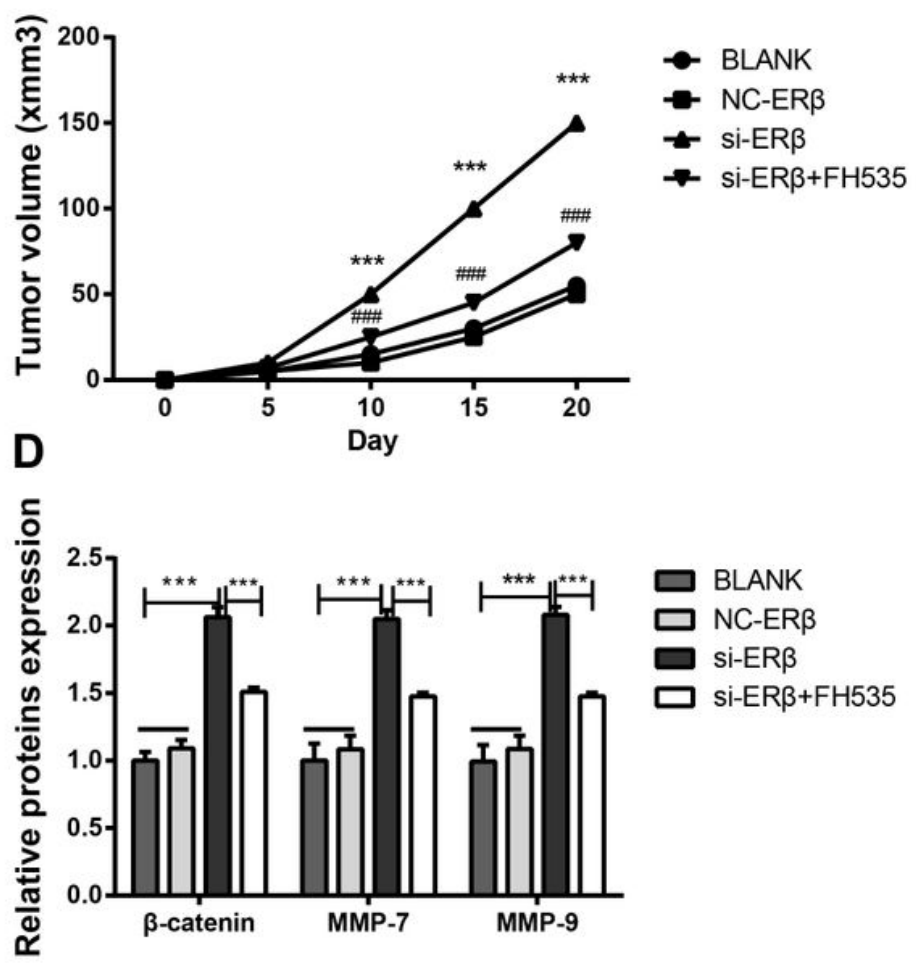

$\mathbf{F}$

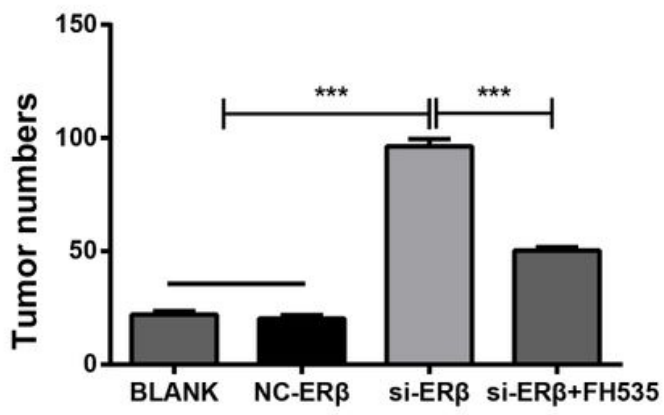

Figure 6

The growth and metastasis of osteosarcoma (OS) tumors in mice. A) subcutaneous tumors under naked eye; B) subcutaneous tumor volumes at different time points; C) protein brands of Western blot; D) relative expression of $\beta$-catenin, MMP-7 and MMP-9 at protein level (Western blot); E) metastatic tumors in the liver tissues of mice under microscope (HE staining) and naked eye; $F$ ) the number of metastatic tumors. si-ER $\beta$, U2-OS cells transfected with siRNA-ER $\beta$ for 48 h; NC-ER $\beta$, U2-OS cells transfected with siRNA-negative control-ER $\beta$ for $48 \mathrm{~h}$; si-ER $\beta$ + FH535, U2-OS cells transfected with siRNA-ER $\beta$ and treated with $20 \mu \mathrm{mol} / \mathrm{L}$ FH535 for $48 \mathrm{~h}$; Blank, U2-OS cells without transfection and treatment. $* \star *, P<0.001$ vs. NC-ERß and blank; \#\#\#, P $<0.001$ vs. si-ERß.

\section{Supplementary Files}

This is a list of supplementary files associated with this preprint. Click to download. 
- NC3RsARRIVEGuidelinesChecklist.docx 